\title{
Comparison of the histogram of oriented gradient, GLCM, and shape feature extraction methods for breast cancer classification using SVM
}

\author{
Hanimatim Mu’jizah, Dian C. Rini Novitasari* \\ Department of Mathematics, Faculty of Science and Technology, UIN Sunan Ampel Surabaya \\ Jl. Ahmad Yani No. 117, Jemur Wonosari, Surabaya, Indonesia 60237
}

\begin{abstract}
How to cite: H. Mu'jizah and DCR. Novitasari, "Comparison of the histogram of oriented gradient, GLCM, and shape feature extraction methods for breast cancer classification using SVM," Jurnal Teknologi dan Sistem Komputer, vol. 9, no. 3, pp. 150-156, 2021. doi: 10.14710/jtsiskom.2021.14104, [Online].
\end{abstract}

\begin{abstract}
Breast cancer originates from the ducts or lobules of the breast and is the second leading cause of death after cervical cancer. Therefore, early breast cancer screening is required, one of which is mammography. Mammography images can be automatically identified using Computer-Aided Diagnosis by leveraging machine learning classifications. This study analyzes the Support Vector Machine (SVM) in classifying breast cancer. It compares the performance of three features extraction methods used in SVM, namely Histogram of Oriented Gradient (HOG), GLCM, and shape feature extraction. The dataset consists of 320 mammogram image data from MIAS containing 203 normal images and 117 abnormal images. Each extraction method used three kernels, namely Linear, Gaussian, and Polynomial. The shape feature extraction-SVM using Linear kernel shows the best performance with an accuracy of $98.44 \%$, sensitivity of $100 \%$, and specificity of $97.50 \%$.
\end{abstract}

Keywords - breast cancer; HOG; GLCM; shape feature extraction; SVM

\section{INTRODUCTION}

Cancer is a deadly tumor due to abnormal cells that grow in the body tissues uncontrollably [1]. Based on data World Health Organization (WHO) in 2013, the second cause of death in the world, as much as $13 \%$, was cancer after cardiovascular disease and is expected to rise in 2030 [2], [3]. One of the highest cancer rates in the world was breast cancer in 2020 [4].

Breast cancer is a cancer of the body tissues originating from the ducts or lobules of the breast [5] Breast cancer has the second-highest cause of death after cervical cancer. The reason is unknown, and its growth is controlled by genes in the nucleus of breast tissue cells. The decrease in genetic factors is only about $5 \%$ to $10 \%$. However, congenital disabilities caused by style are the cause and the first menstrual cycle before 12 years old or women who have menopause after 55 years old [6], [7]. Early breast cancer screening is necessary, one of which is mammography [8].

\footnotetext{
${ }^{*}$ Correspondence author (Dian C. Rini Novitasari)

Email: diancrini@uinsby.ac.id
}

Mammography is an X-ray examination technique that penetrates the breast tissue to see the overall picture of the breast [9]. The results of this technique are still analyzed manually by experienced experts. This research is expected to facilitate medical parties to solve breast cancer identification using Computer-Aided Diagnosis (CAD) [10].

CAD is widely used as decision support in disease detection based on the signal, numerical, and image data [11]. One of the CAD methods that is widely used in classification is the Support Vector Machine (SVM). SVM method can solve problems on patterns (the curse of dimensionality), patterns that are not included in the class can be classified, and easy to apply, so that it is good in classification performance [12], [13]. Vijayarajeswar et al. [14] classified mammogram images using SVM and Hough transform feature extraction. In this research, the best accuracy of SVM reached $94 \%$ compared to LDA, which only obtained $86 \%$. Ma'arif and Arifin [15] conducted another research to classify breast cancer using Backward Elimination (BE) and SVM methods. This study combined BE and SVM feature selection algorithms with data sharing using 10-fold cross-validations. The research obtained an increased accuracy of up to $14 \%$ so that the accuracy value was $97.14 \%$ and the AUC value was 0.995. Based on those studies, it was found that SVM produced high accuracy values.

The classification stage can be carried out if several steps have been carried out, such as feature extraction. Feature extraction aims to extract meaningful information from an image to facilitate the classification stage [16]. The most commonly used feature extraction method is Gray Level Co-occurrence Matrix (GLCM). Tunjungsari et al. [17] researched feature extraction using mammographic images to detect breast cancer using Gray Level Co-occurrence and Fuzzy Backpropagation. This research resulted in an accuracy rate of $50 \%$ with input on FBP, which combines five GLCM features, such as contrast, dissimilarity, energy, entropy, and inverse difference moment. Sarosa et al. [18] researched breast cancer detection on mammographic images using GLCM and SVM feature extraction. This research had a preprocessing stage using a grayscale and histogram equalization, GLCM feature extraction, and SVM classification, with an accuracy of $63.03 \%$. 
Another feature extraction method is the Histogram of Oriented Gradient descriptor (HOG). Suresh et al. [19] researched HOG to examine and classify normal and abnormal patterns on mammographic images using a Deep Neural Network (DBN) by performing preprocessing, segmentation, feature extraction using HOG DBN classification. Such research could achieve increased classification results from $3 \%$ to $9 \%$ compared to other methods. Farhan and Kamil [20] conducted another research to analyze the texture of mammograms using the HOG method. In this research, Contrast Limited Adaptive Histogram Equalization (CLAHE) method was used for preprocessing, feature extraction used was from HOG, and it was classified using the SVM method. The results obtained from this research using a mini-MIAS database were $90 \%$, a sensitivity of $69 \%$, and a specificity of $100 \%$.

Another feature extraction method is shape feature extraction. Wibawa and Novianti [21] conducted a technique to optimize the classification of breast tumors. This study used contour and textural features such as radius, perimeter, area, cohesiveness, smoothness, concave, concave point, symmetry, fractal dimension, and texture. The feature extraction results were classified using the KNN method by comparing feature reduction methods such as PCA, RFE, and RFECV. This research obtained the best accuracy using PCA and KNN of 0.9736 with 1.231 seconds. Ma et al. [22] conducted another research to predict molecular subtypes of breast cancer with mammography radiomic features. The study used 39 attributes, including morphological features such as shape, size, perimeter, area, concavity, roundness, and descriptions of Fourier coefficients and grayscale statistical features and Haralick texture features. The results of this feature extraction used the Naïve Bayes method. The research obtained the best results by combining a craniocaudal and mediolateral oblique appearance with a value of 0.796 to compare triplenegative and non-triple negative.

Research on breast cancer was also carried out in [23] using the Neural Network classification and comparing the GLCM and HOG methods at the feature extraction stage. This study indicates that the proposed method obtains an accuracy of $96.67 \%$ by using HOG. However, the study does not show how fast the Neural Network works. Therefore, this research proposes a further analysis of the SVM method in classifying breast cancer on mammography images by comparing GLCM, HOG methods, and shape feature extraction. This research is expected to provide the best results to help medical authorities classify breast cancer to reduce the death rate of breast cancer.

\section{RESEARCH METHODS}

The research is quantitative research to find the knowledge using data numbers as a tool to analyze the information [24]. The types and sources of data used in this research are secondary data from MIAS (Mammographic Image Analysis Society) consisted of

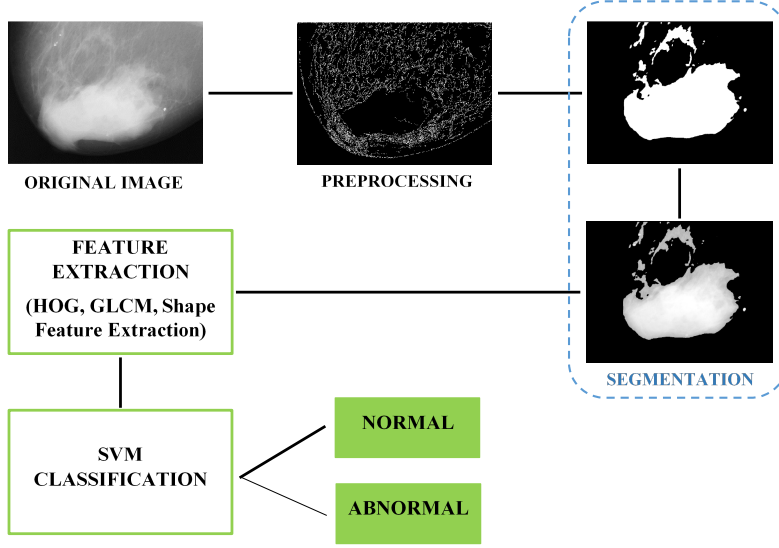

Figure 1. Flowchart on breast cancer classification

320 mammogram images [25]. This data is breast images from the right and left positions (RCC and LCC) in PGM format. In this research, the data were divided into 203 images of normal and 117 images of abnormal. This research consists of various stages, such as the data preprocessing step to improve image quality, segmentation, feature extraction, classification, and model testing, as depicted in Figure 1.

\section{A. Preprocessing and Segmentation}

After the data are obtained, the preprocessing stage is carried out to improve image quality. In this research, the Gaussian filter method is used, and the edge is detected using Canny. The preprocessing of data is carried out again at the segmentation stage. Segmentation is used to separate objects from the background to obtain important objects that will be used in the next stage [26]. This research uses the thresholding method in the segmentation stage.

\section{B. Feature Extraction}

Feature extraction aims to separate relevant information that characterizes each class to form features. This feature will be used in the classification stage to introduce the input unit to the target output to be easier in the classification stage [27]. In this research, feature extraction process compares HOG method [28] [30], GLCM [31]-[34], and shape feature extraction [35]-[37]. In this research, GLCM uses four parameters, namely contrast, correlation, energy, and homogeneity. Feature extraction uses four parameters, namely area, perimeter, metric, and eccentricity.

\section{Classification}

The image from the feature extraction stage is classified using SVM [38]-[40]. Image data is divided into test data and training data using the k-fold crossvalidation method. The classification results are tested using a confusion matrix with the accuracy, sensitivity, and specificity parameters to determine the method's accuracy in the image data used [33]. 


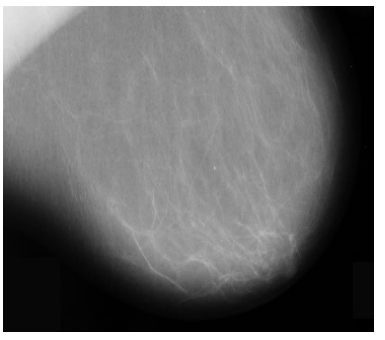

(a) normal

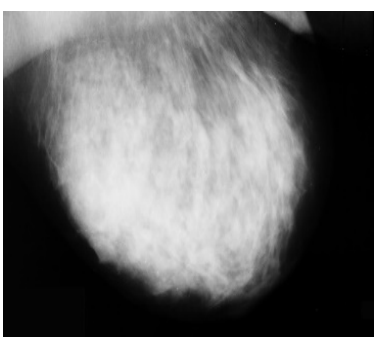

(b) abnormal
Figure 2. Sample data images

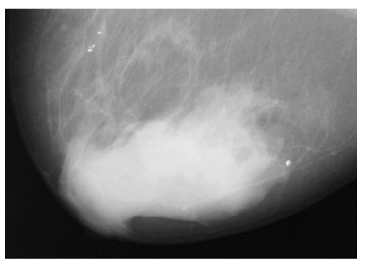

(a) Original image

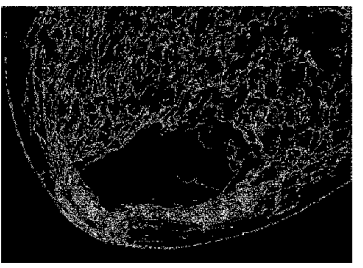

(c) Canny edge detection

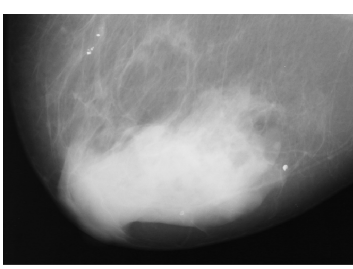

(b) Gaussian filter

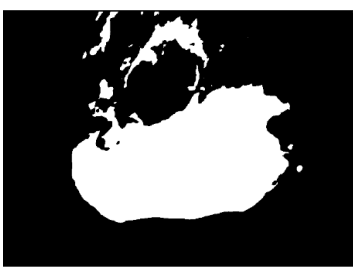

(d) Thresholding
Figure 3. Preprocessing and segmentation stages

\section{RESULTS AND DISCUSSION}

The result of this study is the accuracy value of the classification results to measure the success of the model used. The steps taken are preprocessing, segmentation, feature extraction, and classification. Figure 2 shows the data sample used in this study.

\section{A. Preprocessing and segmentation}

This stage begins with cropping to focus on the breast area. In this research, cropping was done manually by the authors. The following process is preprocessing using a Gaussian filter to smoothen and reduce noise in the image. The following process is Canny edge detection to make it easier to identify objects at the segmentation stage. Furthermore, the segmentation stage was carried out using thresholding. Figure 3 shows the results of the preprocessing and segmentation stages.

\section{B. Feature Extraction}

Feature extraction is used to identify the characteristics of each image at the classification stage. In this research, the feature extraction used HOG, GLCM, shape feature extraction, which will later be used as a comparison at the model testing stage. The HOG feature extraction used nine blocks so that each image will be divided into $3 \times 3$. The results of HOG samples are shown in Table 1. The GLCM feature
Table 1. Results of HOG samples

\begin{tabular}{|c|c|c|c|c|c|}
\hline \multirow{2}{*}{ Data } & \multicolumn{4}{|c|}{ Features } & \multirow{2}{*}{ Class } \\
\hline & 1 & 2 & $\ldots$ & 81 & \\
\hline 1 & 0.16 & 0.36 & $\ldots$ & 0.19 & Normal \\
\hline 2 & 0.22 & 0.30 & $\ldots$ & 0.23 & \\
\hline 3 & 0.18 & 0.24 & $\ldots$ & 0.22 & \\
\hline 4 & 0.19 & 0.25 & $\ldots$ & 0.24 & \\
\hline 5 & 0.20 & 0.30 & $\ldots$ & 0.21 & \\
\hline$\ldots$ & $\ldots$ & $\ldots$ & $\ldots$ & $\ldots$ & \\
\hline 204 & 0.12 & 0.20 & $\ldots$ & 0.20 & Abnormal \\
\hline 205 & 0.20 & 0.25 & $\ldots$ & 0.22 & \\
\hline 206 & 0.14 & 0.17 & $\ldots$ & 0.19 & \\
\hline 207 & 0.17 & 0.28 & $\ldots$ & 0.21 & \\
\hline 208 & 0.21 & 0.27 & $\ldots$ & 0.23 & \\
\hline$\ldots$ & $\ldots$ & $\ldots$ & $\ldots$ & $\ldots$ & \\
\hline
\end{tabular}

Table 2. Results of GLCM samples

\begin{tabular}{cccccc}
\hline Deg ( $\left(^{\mathbf{}}\right)$ & Ct & Cr & En & H & Class \\
\hline 0 & 0.02 & 1.00 & 0.41 & 0.99 & Normal \\
45 & 0.04 & 1.00 & 0.41 & 0.99 & \\
90 & 0.03 & 1.00 & 0.41 & 0.99 & \\
135 & 0.04 & 1.00 & 0.41 & 0.99 & \\
0 & 0.03 & 1.00 & 0.46 & 0.99 & Abnormal \\
45 & 0.04 & 1.00 & 0.46 & 0.99 & \\
90 & 0.03 & 1.00 & 0.46 & 0.99 & \\
135 & 0.05 & 1.00 & 0.46 & 0.99 & \\
\hline
\end{tabular}

Table 3. Results of shape feature extraction samples

\begin{tabular}{ccccc}
\hline Per & A & Mtr & Ecc & Class \\
\hline 2478252 & $7.87 \times 10^{3}$ & 0.50 & 0.84 & Normal \\
4933748 & $9.19 \times 10^{3}$ & 0.65 & 0.72 & \\
847 & 116.48 & 0.65 & 0.90 & \\
3794909 & $8.92 \times 10^{3}$ & 0.63 & 0.74 & \\
1353547 & $8.42 \times 10^{3}$ & 0.55 & 0.88 & \\
1471591 & $7.44 \times 10^{3}$ & 0.32 & 0.61 & Abnormal \\
2704535 & $7.77 \times 10^{3}$ & 0.32 & 0.81 & \\
880 & 115.74 & 0.32 & 0.86 & \\
3026472 & $687 \times 10^{3}$ & 0.32 & 0.71 & \\
1647 & 176.29 & 0.32 & 0.86 & \\
\hline
\end{tabular}

extraction used four parameters, namely contrast $(C t)$, correlation $(C r)$, energy $(E n)$, and homogeneity $(H)$. The results of GLCM samples can be seen in Table 2. There are four parameters in shape feature extraction in this research, namely area $(A)$, perimeter (Per), metric (Mtr), and eccentricity $(E c c)$. Table 3 shows the results of shape feature extraction samples.

The process before classification is data sharing. The data is divided into training and test data using the $\mathrm{k}$-fold cross-validation method. In this research, the used $\mathrm{k}$ value was 5, which obtains the highest classification accuracy reported so far after the $\mathrm{K}$ test from 2 to 10 in [41]. Therefore, the data was divided into 256 images for training data and 64 images for testing data. 


\section{Classification}

The data from feature extraction is classified into two classes, namely normal and abnormal. The data classification uses the SVM method. In this research, the SVM method uses Linear, Gaussian, and Polynomial kernels. The classification results are expressed in a confusion matrix to calculate accuracy (Acc), sensitivity (Sens), and specificity (Spec). The confusion matrix can be seen in Table 4 .

Based on Table 4, HOG-SVM has 8 data classified as positive cancer, 4 data falsely classified as positive cancer, 16 data falsely classified as negative cancer, and 36 data classified as negative cancer. In the GLCM-SVM, there are 8 data classified as positive cancer, 4 data falsely classified as positive cancer, 15 data falsely classified as negative cancer, and 37 data classified as negative cancer. In the shape feature extraction-SVM, there are 24 data classified as positive cancer, 1 data falsely classified as positive cancer, 0 data falsely classified as negative cancer, and 39 data classified as negative.

Table 5 shows that the best accuracy is obtained using the Gaussian kernel with an accuracy of $68.75 \%$. The best results on sensitivity are achieved at $33.33 \%$ using Gaussian and Linear kernel. The best specificity is reached using a Gaussian kernel of $90.00 \%$. Based on these results, HOG-SVM classification obtains the best performance using the Gaussian kernel with 0.04 seconds for computational time $T$ [42].

Table 6 shows that the Gaussian kernel with $0^{\circ}$ has an accuracy of $54.69 \%$ with sensitivity and specificity values of $12.50 \%$ and $80.00 \%$ with 0.05 seconds for computational time. Therefore, this kernel is not a good classifier. This poor accuracy results are caused by the GLCM result data that cannot be appropriately separated [34]. The best results are obtained using a Gaussian kernel with $45^{\circ}$ with $70.31 \%$ accuracy, $34.78 \%$ sensitivity, and $90.24 \%$ specificity. It gives better accuracy than [17], [18]. Therefore, GLCM-SVM gains the best results with the Gaussian kernel with 0.03 seconds for computational time. The Gaussian kernel explains data distribution better than the Polynomial and Linear kernels in the data mapping process [43].

Table 7 reveals that the best accuracy is obtained using a Linear kernel of $98.44 \%$. The best sensitivity is obtained using a Linear and Gaussian kernel with a sensitivity value of $100 \%$. For specificity, the best results are obtained using a Linear kernel at $97.50 \%$. The Linear kernels explain data distribution better than the Polynomial and Gaussian kernels in the data mapping process [44]. Based on these results, shape feature extraction-SVM classification obtains the best results using the Linear kernel with 0.04 seconds for computational time. The results show that shape feature extraction-SVM using a Linear kernel is the best model. It gives better accuracy than [45]. HOG and GLCM obtain lower accuracy values than shape feature extraction. In the segmentation process, the image is from a binary image converted back to a grayscale image caused some features are missing [46].
Table 4. The classification results

\begin{tabular}{lcccc}
\hline \multicolumn{1}{c}{ Methods } & TP & TN & FP & FN \\
\hline HOG-SVM & 8 & 36 & 4 & 16 \\
GLCM-SVM & 8 & 37 & 4 & 15 \\
Shape Feature & 24 & 39 & 1 & 0 \\
Extraction-SVM & & & & \\
\hline
\end{tabular}

Table 5. HOG-SVM classification performance

\begin{tabular}{ccccc}
\hline Kernel & Acc (\%) & Sens (\%) & Spec (\%) & T (s) \\
\hline Linear & 57.81 & 33.33 & 72.50 & 0.06 \\
Gaussian & 68.75 & 33.33 & 90.00 & 0.04 \\
Polynomial & 57.81 & 37.50 & 70.00 & 0.05 \\
\hline
\end{tabular}

Table 6. GLCM-SVM classification performance

\begin{tabular}{cccccc}
\hline Kernel & Deg $\mathbf{(}^{\mathbf{}}$ ) & Acc (\%) & Sens (\%) & Spec (\%) & T (s) \\
\hline Linear & 0 & 64.06 & 8.33 & 97.50 & 0.04 \\
& 45 & 65.63 & 4.00 & 100.00 & 0.06 \\
& 90 & 65.63 & 8.33 & 100.00 & 0.04 \\
Gaussian & 135 & 64.62 & 4.00 & 100.00 & 0.03 \\
& 45 & 54.69 & 12.50 & 80.00 & 0.05 \\
& 90 & 62.31 & 34.78 & 90.24 & 0.03 \\
& 135 & 60.00 & 4.00 & 92.50 & 0.04 \\
Polyno & 0 & 67.19 & 16.67 & 97.50 & 0.04 \\
mial & 45 & 62.50 & 8.70 & 92.68 & 0.03 \\
& 90 & 57.81 & 8.33 & 87.50 & 0.04 \\
& 135 & 61.15 & 12.50 & 97.56 & 0.04 \\
\hline
\end{tabular}

Table 7. HOG-SVM classification performance

\begin{tabular}{ccccc}
\hline Kernel & Acc (\%) & Sens (\%) & Spec (\%) & T (s) \\
\hline Linear & 98.44 & 100.0 & 97.50 & 0.04 \\
Gaussian & 96.88 & 95.83 & 97.50 & 0.05 \\
Polynomial & 96.88 & 97.50 & 95.83 & 0.03 \\
\hline
\end{tabular}

\section{CONCLUSION}

Research to identify breast cancer has been proposed by comparing feature extraction and classification using SVM. The proposed method obtains good accuracy with fast computation time. Feature shape extraction methods are capable of detecting the presence of cancer. SVM classification is very good at identifying breast cancer compared to using neural networks in previous studies. Further research is expected to be carried out using appropriate classification methods with fast computation time.

\section{SUPPLEMENTARY MATERIALS}

Supplementary material associated with this article can be found, in the online version, at doi: 10.14710/jtsiskom.2021.14104. 


\section{REFERENCES}

[1] A. Deverakonda and N. Gupta, "Diagnosis and treatment of cervical cancer : A review,” Research and Reviews Journal of Medical \& Health Sciences, vol. 5, no. 3, pp. 1-11, 2016.

[2] R. L. Siegel, K. D. Miller, and A. Jemal, "Cancer statistics, 2019," CA: A Cancer Journal for Clinicians, vol. 69, no. 1, pp. 7-34, 2019. doi: 10.3322/caac. 21551

[3] E. Weisshaar, "Cancers," in Pruritus, 2nd Ed. Cham: Springer, 2016, pp. 283-287. doi: 10.1007/978-3-319-33142-3_37

[4] H. Sung et al., "Global cancer statistics 2020: GLOBOCAN estimates of incidence and mortality worldwide for 36 cancers in 185 countries," CA: A Cancer Journal of Clinicians, vol. 71, no. 2, pp. 209-249, 2021. doi: 10.3322/caac. 21660

[5] B. Brahma et al., "The predictive value of methylene blue dye as a single technique in breast cancer sentinel node biopsy: A study from Dharmais Cancer Hospital," World Journal of Surgical Oncology, vol. 15, no. 1, pp. 1-7, 2017. doi: 10.1186/s12957-017-1113-8

[6] M. Dewi, "Sebaran kanker di Indonesia, riset kesehatan dasar 2007," Indonesian Journal of Cancer, vol. 11, no. 1, pp. 1-8, 2017.

[7] Y. S. Sun et al., "Risk factors and preventions of breast cancer," International Journal of Biological Sciences, vol. 13, no. 11, pp. 1387-1397, 2017. doi: 10.7150/ijbs.21635

[8] S. C. Harvey et al., "Systematic review of 3D mammography for breast cancer screening," The Breast, vol. 27, pp. 52-61, 2016. doi: 10.1016/j.breast.2016.01.002

[9] H. G. Welch, P. C. Prorok, A. J. O’Malley, and B. S. Kramer, "Breast-cancer tumor size, overdiagnosis, and mammography screening effectiveness," New England Journal of Medicine, vol. 375, no. 15, pp. 1438-1447, 2016. doi: 10.1056/NEJMoa1600249

[10] N. I. R. Yassin, S. Omran, E. M. F. El Houby, and H. Allam, "Machine learning techniques for breast cancer computer aided diagnosis using different image modalities: A systematic review,” Computer Methods and Programs in Biomedicine, vol. 156, pp. 25-45, 2018. doi: 10.1016/j.cmpb.2017.12.012

[11] D. C. R. Novitasari, A. Z. Foeady, M. Thohir, A. Z. Arifin, K. Niam, and A. H. Asyhar, "Automatic approach for cervical cancer detection based on deep belief network (DBN) using colposcopy data," in International Conference on Artificial Intelligence in Information and Communication, Fukuoka, Japan, Feb. 2020, pp. 415-420. doi: 10.1109/ICAIIC48513.2020.9065196

[12] N. Nurajijah and D. Riana, “Algoritma naïve bayes, decision tree, dan SVM untuk klasifikasi persetujuan pembiayaan nasabah koperasi syariah,” Jurnal Teknologi dan Sistem Komputer, vol. 7, no. 2, pp. 77-82, 2019. doi: 10.14710/jtsiskom.7.2.2019.77-82

[13] N. Z. Kurniawan, S. T. Rasmana, and Y. Triwidyastuti, "Identifikasi jenis penyakit daun tembakau menggunakan metode gray level cooccurrence matrix (GLCM) dan support vector machine (SVM)," JCONES Journal of Control and Network Systems, vol. 3, no. 1, pp. 46-53, 2016.

[14] R. Vijayarajeswari, P. Parthasarathy, S. Vivekanandan, and A. A. Basha, "Classification of mammogram for early detection of breast cancer using SVM classifier and hough transform," Measurement: Journal of the International Measurement Confederation, vol. 146, pp. 800-805, 2019. doi: 10.1016/j.measurement.2019.05.083

[15] F. Ma’arif and T. Arifin, “Optimasi fitur menggunakan backward elimination dan algoritma SVM untuk klasifikasi kanker payudara,” Jurnal Informatika, vol. 4, no. 1, pp. 46-53, 2017.

[16] M. Nixon and A. Aguado, Feature extraction and image processing for computer vision, 5th ed. London: Academic press, 2019. doi: B978-0-12814976-8.00003-8

[17] E. F. Tunjungsari, R. Apsari, and E. Purwanti, "Deteksi dini kanker payudara dari citra mammografi menggunakan gray level cooccurence matrices (GLCM) dan fuzzy backpropagation,” Jurnal Fisika dan Terapannya, vol. 4, no. 1, pp. 81-94, 2016.

[18] S. J. A. Sarosa, F. Utaminingrum, and F. A. Bachtiar, "Mammogram breast cancer classification using gray-level co-occurrence matrix and support vector machine," in International Conference on Sustainable Information Engineering and Technology, Malang, Indonesia, Nov. 2018, pp. 5459. doi: 10.1109/SIET.2018.8693146

[19] R. Suresh, A. N. Rao, and B. E. Reddy, "Detection and classification of normal and abnormal patterns in mammograms using deep neural network," Concurrency Computation, vol. 31, no. 14, pp. 112, 2019. doi: 10.1002/cpe.5293

[20] A. H. Farhan and M. Y. Kamil, "Texture analysis of mammogram using histogram of oriented gradients method," IOP Conference Series: Materials Science and Engineering, vol. 881, 012149, 2020. doi: 10.1088/1757-899X/881/1/012149

[21] M. S. Wibawa and K. D. P. Novianti, "Reduksi fitur untuk optimalisasi klasifikasi tumor payudara berdasarkan data citra FNA," in Konferensi Nasional Sistem \& Informatika, Bali, Indonesia, Aug. 2017, pp. 73-78.

[22] W. Ma et al., "Breast cancer molecular subtype prediction by mammographic radiomic features," Academic Radiology, vol. 26, no. 2, pp. 196-201, 2019. doi: 10.1016/j.acra.2018.01.023

[23] K. C. Tatikonda, C. M. Bhuma, and S. K. Samayamantula, "The analysis of digital mammograms using HOG and GLCM features," in International Conference on Computing, Communication and Networking Technologies, 
Bengaluru, India, Jul. 2018, pp. 1-7. doi: 10.1109/ ICCCNT.2018.8493809

[24] J. Brannen, Mixing methods: Qualitative and quantitative research. New York: Routledge, 2017. doi: 10.4324/9781315248813

[25] J. Suckling et al., "Mammographic Image Analysis Society (MIAS) database v1.21 [Dataset],” Apollo, 2015. Available: https://www.repository.cam.ac.uk/ handle/1810/250394

[26] D. C. R. Novitasari, "Klasifikasi alzheimer dan non alzheimer menggunakan fuzzy c-mean, gray level co-occurence matrix dan support vector machine," Jurnal Matematika “MANTIK," vol. 4, no. 2, pp. 83-89, 2018. doi: 10.15642/mantik.2018.4.2.83-89

[27] R. Venkateswari, "Brain tumor segmentation based on GLCM feature extraction using probabilistic neural network," International Journal of Engineering Science and Computing, vol. 7, no. 7, pp. 14031-14035, 2017.

[28] D. Alamsyah, "Pengenalan mobil pada citra digital menggunakan HOG-SVM,” Jatisi, vol. 1, no. 2, pp. 162-168, 2017.

[29] F. D. Adhinata, M. Ikhsan, and W. Wahyono, "People counter on CCTV video using histogram of oriented gradient and kalman filter methods," Jurnal Teknologi dan Sistem Komputer, vol. 8, no. 3, pp. 222-227, 2020. doi: 10.14710/jtsiskom.2020.13660

[30] S. A. Korkmaz, A. Akcicek, H. Binol, and M. F. Korkmaz, "Recognition of the stomach cancer images with probabilistic HOG feature vector histograms by using HOG features," in IEEE International Symposium on Intelligent Systems and Informatics, Subotica, Serbia, Sept. 2017, pp. 339-342. doi: 10.1109/SISY.2017.8080578

[31] A. Z. Foeady, D. C. R. Novitasari, A. H. Asyhar, and M. Firmansjah, "Automated diagnosis system of diabetic retinopathy using GLCM method and SVM classifier," in International Conference on Electrical Engineering, Computer Science and Informatics, Malang, Indonesia, Oct. 2018, pp. 154-160. doi: 10.1109/EECSI.2018.8752726

[32] D. C. R. Novitasari, A. Lubab, A. Sawiji, and A. H. Asyhar, "Application of feature extraction for breast cancer using one order statistic, GLCM, GLRLM, and GLDM," Advances in Science, Technology and Engineering Systems Journal, vol. 4, no. 4, pp. 115-120, 2019. doi: 10.25046/aj040413

[33] D. C. R. Novitasari, A. H. Asyhar, M. Thohir, A. Z. Arifin, H. Mu'jizah, and A. Z. Foeady, "Cervical cancer identification based texture analysis using GLCM-KELM on colposcopy data," in International Conference on Artificial Intelligence in Information and Communication, Fukuoka, Japan, Feb. 2020, pp. 409-414. doi: 10.1109/ICAIIC48513.2020.9065252

[34] M. Thohir, A. Z. Foeady, D. C. R. Novitasari, A. Z. Arifin, B. Y. Phiadelvira, and A. H. Asyhar, "Classification of colposcopy data using GLCMSVM on cervical cancer," in International
Conference on Artificial Intelligence in Information and Communication, Fukuoka, Japan, Feb. 2020, pp. 373-378, 2020. doi: 10.1109/ICAIIC48513.2020.9065027

[35] P. S. S. Kumar and V. S. Dharun, "Extraction of texture features using GLCM and shape features using connected regions," International Journal of Engineering and Technology, vol. 8, no. 6, pp. 29262930, 2016. doi: 10.21817/ijet/2016/v8i6/160806254

[36] A. A. Kasim, R. Wardoyo, and A. Harjoko, "Batik classification with artificial neural network based on texture-shape feature of main ornament," International Journal of Intelligent Systems and Applications, vol. 9, no. 6, pp. 55-65, 2017. doi: 10.5815/ijisa.2017.06.06

[37] L. Ratnawati and D. R. Sulistyaningrum, "Penerapan random forest untuk mengukur tingkat keparahan penyakit pada daun apel,” Jurnal Sains dan Seni ITS, vol. 8, no. 2, pp. A71-A77, 2019.

[38] D. C. R. Novitasari et al., "Whirlwind classification with imbalanced upper air data handling using SMOTE algorithm and SVM classifier," Journal of Physics: Conference Series, vol. 1501, no. 1, 012010, 2020. doi: 10.1088/17426596/1501/1/012010

[39] D. C. R. Novitasari et al., "Detection of COVID-19 chest $\mathrm{x}$-ray using support vector machine and convolutional neural network," Communications in Mathematical Biology and Neuroscience, vol. 2020, pp. 1-19, 2020. doi: 10.28919/cmbn/4765

[40] D. C. R. Novitasari, M. F. Rozi, and R. Veriani, "Klasifikasi kelainan pada jantung melalui citra iris mata menggunakan fuzzy c-means sebagai pengambil fitur iris dan klasifikasi menggunakan support vector machine," INTEGER: Journal of Information Technology, vol. 4, no. 1, pp. 1-10, 2019. doi: 10.31284/j.integer.2019.v4i1.489

[41] T.-T. Wong and N.-Y. Yang, "Dependency analysis of accuracy estimates in k-fold cross validation," IEEE Transactions on Knowledge and Data Engineering, vol. 29, no. 11, pp. 2417-2427, 2017. doi: 10.1109/TKDE.2017.2740926

[42] C. Yao, F. Wu, H. J. Chen, X. L. Hao, and Y. Shen, "Traffic sign recognition using hog-svm and grid search," in International Conference on Signal Processing, Hangzhou, China, Oct. 2014, 1, pp. 962-965. doi: 10.1109/ICOSP.2014.7015147

[43] A. Pratama, R. C. Wihandika, and D. E. Ratnawati, "Implementasi algoritme support vector machine (SVM) untuk prediksi ketepatan waktu kelulusan mahasiswa," Jurnal Pengembangan Teknologi Informasi dan Ilmu Komputer, vol. 2, pp. 1704 1708, 2018.

[44] P. K. Intan, "Comparison of kernel function on support vector machine in classification of childbirth,” Jurnal Matematika MANTIK, vol. 5, no. 2, pp. 90-99, 2019. doi: 10.15642/mantik.2019.5.2.90-99

[45] A. Bakhshipour and A. Jafari, "Evaluation of support vector machine and artificial neural 
networks in weed detection using shape features," Computers and Electronics in Agriculture, vol. 145, no. 2017, pp. 153-160, 2018. doi: 10.1016/j.compag.2017.12.032

[46] R. R. Waliyansyah, K. Adi, and J. E. Suseno, "Implementasi metode gray level co-occurrence matrix dalam identifikasi jenis daun tengkawang," Jurnal Nasional Teknik Elektro dan Teknologi Informasi (JNTETI), vol. 7, no. 1, pp. 50-56, 2018. doi: 10.22146/jnteti.v7i1.400

밍 (C)2021. This open-access article is distributed under the terms and conditions of the Creative Commons Attribution-ShareAlike 4.0 International License. 